\title{
CONTEMPORARY ISLAMIC THOUGHT IN INDONESIAN AND MALAY WORLD Islam Liberal, Islam Hadhari, and Islam Progresif'
}

\author{
Kamaruzzaman Bustamam-Ahmad \\ IAIN Ar-Raniry, Banda Aceh - Indonesia
}

\begin{abstract}
Islam in Indonesian and Malay world is very much heterogenuous. Taking Islam Liberal, Islam Hadhari, and Islam Progresif as the subject of analysis, this article deals with the concepts Islam Liberal, Islam Hadhari, and Islam Progresif as products of the trends in Islamic thinking, the impact of these three interpretations of Islam in Malaysia and Indonesia, the similarities and dissimilarities between the three, and their future prospects in the region. It argues that the prominence of the debates surrounding the three currents of Islamic thought is the result of struggles for power and authority in Islamic discourse in the region. It further argues that the Indonesian-based Islam Liberal differs from the Malaysian-based Islam Hadhari in that it does not originate from government sources. Islam Progresif is more of an umbrella term referring to various strands of thought developed by Muslims opposed to the status quo. Although Islam Hadhari is a newly-coined term, it contains many elements in common with other schools of Islamic thought including Islam Liberal and neo-modernist Islam.
\end{abstract}

Keywords: Islam Liberal, Islam Hadhari, Islam Progresif Islamic thought, Indonesian-Malay World.

\section{Introduction}

The diversity of currents in Islamic thought has enriched the development of Islam in Southeast Asia. Islam Liberal ("Liberal Islam"), Islam Hadhari ("Civilizational Islam"), and Islam Progresif ("Progressive ${ }^{1}$ I wish to thank Patrick Jory and Ronald Lukens-Bull for their valuable comments
during the preparation of this article. 
Islam") are currents in recent development of Islamic thought in this region. Geographically Islam Liberal is a concept developed by young intellectual activists in Indonesia linked to the Islamic organizations Nahdlatul Ulama (NU) and Muhammadiyah. ${ }^{2}$ Islam Hadhari is an officially-controlled version of Islam promoted by former Malaysian Prime Minister Abdullah Badawi. Islam Progresif is an umbrella term referring to a school of Islamic thought that could at once be described as liberal, moderate, or puritan. ${ }^{3}$

To be sure, there are many other versions of Islam in Southeast Asia, particularly Indonesia. In terms of organizations, NU and Muhammadiyah are the largest Muslim organizations not only in Indonesia but also in Southeast Asia. They also have own interpretations of Islam, and their members tend to be staunch followers. Great diversity also exists in the practices of and approaches to Islam in areas such as Aceh, Padang, Java, Lombok, and Kalimantan. ${ }^{4}$ In sum, the development of Islam in Indonesia is very much heterogenuous. ${ }^{5}$

This article addresses four main questions; how the concepts Islam Liberal, Islam Hadhari, and Islam Progresif are products of certain trends in Islamic thinking, the impact of these three interpretations of Islam in Southeast Asia (especially in Malaysia and Indonesia), the similarities

2 See Kamaruzzaman Bustamam-Ahmad, "Islam Hadhari and Islam Liberal in Southeast Asia," in Congress of Democrats from the Islamic World "Beyond Elections: Islam and Political Parties in Southeast Asia" (Jakarta: National Democratic Institute, 2005). Kamaruzzaman Bustamam-Ahmad, Wajah Baru Islam Di Indonesia (Yogyakarta: UII Press, 2004). Kamaruzzaman Bustamam-Ahmad, "Metamorfosis Pemikiran Intelektual Muda NU: Suatu Pandangan Dari Outsider NU," Millah 4, 1 (2004). M.A. Fattah Santoso, "Fenomena Jaringan Islam Liberal (JIL) Sebuah Studi Pendahuluan," Profetika: Jurnal Studi Islam 5, no. 2 (2003): pp. 155-179.

3 See Omid Safi, "What Is Progressive Islam," ISIM Newsletter, no. 13 (2003), pp. 4849; Farish A. Noor, "The Challenges and Prospects for 'Progressive Islam' in Southeast Asia: Reclaiming the Faith in the Age of George Bush and Osama Ben Laden," ICIP JOURNAL 1, no. 1 (2004): pp. 1-31; Khaled Aboue El Fadl, The Great Theft: Wrestling Islam from the Extremists (San Francisco: Harper San Francisco, 2005).

${ }^{4}$ See generally, Erni Budiwanti, "The Impact of Islam on the Religion of the Sasak in Bayan, West Lombok," Kultur 2, no. 2 (2001): pp. 29-40; Bustamam-Ahmad, Wajah Baru Islam Di Indonesia. Nina Herlina Lubis, "Religious Thoughts and Practices of the Kaum Menak: Strengthening Traditional Power," Studia Islamika 10, no. 2 (2003): pp. 1-31.

${ }^{5}$ Nurcholish Madjid, "Islamic Roots of Modern Pluralism: Indonesian Experiences," Studia Islamika 1, no. 1 (1994), p. 60. 
and dissimilarities between the three, and their future prospects in the region. It argues that the prominence of the debates surrounding the three currents is the result of struggles for power and authority in Islamic thought in the region.

\section{Mapping Islamic Thought in Southeast Asia}

Azyumardi Azra has argued that Southeast Asian Islam historically, sociologically, culturally and politically has often been regarded as marginal and peripheral vis-à-vis Middle Eastern Islam. ${ }^{6}$ But to say that Southeast Asia Islam is not very Islamized is misleading. Although Islam in Southeast Asia may not resemble Islam in the Middle East, Islam in Southeast Asia is indeed already Islamized, its development is a result of the process of compromise between Islam and local cultures. Historically speaking, there has been little tension between Islam and local tradition, except when the Dutch scholars in Indonesia attempted to differentiate Islam from local tradition in order to clarify the source of law of the indigenous people. ${ }^{7}$

In early development of Islamic thought in Southeast Asia, most of the works by 'ulama', who served Islamic kingdoms such as Aceh, Melaka, and Pattani were a response to issues concerning the ummah on the orders of the Sultan. The works of Nurdin Ar-Raniri, Sirat alMustaqim (1634), and Abdul Rauf Singkeli, Mir'at al-Tullab (1663), are prominent examples of Islamic voices within this generation. ${ }^{8}$ Even

\footnotetext{
6 Azyumardi Azra, "Islam in Southeast Asia: Tolerance and Radicalism," (Paper presented at Miegunyah Public Lecture, The University of Melbourne, Wednesday 6 April 2005), p. 129; Azyumardi Azra, "Southeast Asian Islam in the Post-Bali Bombing: Debunking the Myth", in Norbert Eschborn et al. (eds.), Indonesia Today: Problems \& Perspectives (Jakarta: Konrad Adenauer Stiftung, 2004), p. 143.

${ }^{7}$ Harry J. Benda, "Christian Snouck Hurgronje and the Foundations of Dutch Islamic Policy in Indonesia," The Journal of Modern History 30, 4 (1958), pp. 338-347. See also Ratno Lukito, "The Role of Custom in the Formation of Islamic Law," McGill Journal of Middle East Studies 5 (1997), pp. 5-31. Ratno Lukito, "Islamic Law and the Colonial Encounters: The Experience of India and Indonesia," in Yudian Wahyudi, Akh. Minhaji, and Amirul Hadi (eds), The Dynamics of Islamic Civilization (Yogyakarta: Titian Ilahi Press, 1998), pp. 209-230; Ratno Lukito, Islamic Law and Adat Encounter: The Experience of Indonesia (Jakarta: Logos, 2001); Ratno Lukito, Pergumulan Antara Hukum Islam dan Adat di Indonesia (Jakarta: INIS, 1998).

8 See Bustamam-Ahmad, Wajah Baru Islam Di Indonesia, pp. 311-326; Ahmad Daudy, Syeikh Nuruddin Ar-Raniry (Sejarah, Karya dan Sanggahan terbadap Wujudiyyah di Aceh) (Jakarta: Bulan Bintang, 1978); Oman Fathurahman, Tanbīh Al-Mäsyi Menyoal Wabdatul Wujud: Kasus Abdurrauf Singkel Di Aceh Abad 17 (Bandung: Mizan, 1999); HP. Daly,
} 
though these works are concerned with Islamic law, it seems that Islamic thought had a close relationship with both Southeast Asian Islamic kingdoms and Haramayn (Makkah and Madinah). ${ }^{9}$ The key point, as Azra argues in his dissertation, is that this era represents the first period of Islamic reformism in Southeast Asia. ${ }^{10}$ Azra identifies Nurdin Ar-Raniri as one of the most important early mujaddids (reformists) in the Archipelago. ${ }^{11}$ According to Peter G. Riddel, in fulfilling this role ar-Raniri was transmitting the reformist pulses originating in both Arabia and India, thereby stimulating the Islamization of the archipelago. ${ }^{12}$

The second phase of Islamic thought in Southeast Asia began when Muslim thinkers started to be influenced by Islamic reformism in Middle East in the nineteenth and early twentieth centuries. Since converting to Islam the Malays have traditionally had a high reverence for the Hijaz - which holds the two holy cities, Makkah and Madinah and its 'ulama', whom they regard as a source of religious and political authority, when the need for an authoritative decision arises. ${ }^{13}$ In this

Hukum Perkawinan Islam: Suatu Studi Perbandingan dalam Kalangan Ablul-Sunnah dan Negara-Negara Islam (Jakarta: Bulan Bintang, 1989).

${ }^{9}$ On this see also Mohammad Redzuan Othman, Islam Dan Masyarakat Melayu: Peranan Timur Tengah (Kuala Lumpur: UM Press, 2005), pp. 63-81.

10 See Azyumardi Azra, "The Transmission of Islamic Reformism to Indonesia: Networks of Middle Eastern and Malay-Indonesian 'Ulama' in the Sevententh and Eighteenth Centuries" (Unpublished Ph.D Dissertation, Columbia University, 1992), p. 351.

11 See Azyumardi Azra, Islam Reformis Dinamika Intelektual dan Gerakan (Jakarta: Raja Grafindo Persada, 1999), pp. 166-8; Azyumardi Azra, The Origins of Islamic Reformism: Networks of Malay-Indonesian and Middle Eastern 'Ulama in the 17th and 18th Centuries (Hawaii: University of Hawaii Press, 2004); Bustamam-Ahmad, Wajah Baru Islam di Indonesia, p. 304. About Azyumardi Azra see Kamaruzzaman Bustamam-Ahmad, "Kontribusi Azyumardi Azra dalam Studi Sejarah Sosial Islam di Asia Tenggara," Profetika: Jurnal Studi Islam 5, 2 (2003): pp. 180-204; Kamaruzzaman Bustamam-Ahmad, "Studi Sejarah Sosial Islam di Asia Tenggara: Kontribusi Azyumardi Azra," Mimbar Agama \& Budaya XX, 3 (2003): pp. 249-70.

12 Peter G. Riddel, "Schools of Islamic Thought in Southeast Asia," in Islam in Southeast Asia and China: Regional Faithlines and Faultlines on the Global Ummab (Hong Kong: 2002).

3. See also Peter G. Riddel, Islam and the Malay-Indonesian World: Transmission and Responses (Singapore: Horizon Books, 2003), pp. 101-139.

${ }^{13}$ Mohammad Redzuan Othman, "In Search of and Islamic Leader: Malay Perceptions of Ibn Sa'ud and the Domination of the Wahhabīs Saudi Arabia," Studia Islamika 11, 2 (2004), p. 261. 
phase the dynamics of Islamic intellectualism in Southeast Asia were influenced by the Middle East in a number of ways. First, pilgrimage to the Hijaz was seen as part of the process of learning Islam from "the true area of Islam" in the world. Some Malays did not return to the Archipelago because they wanted to continue their studies at Haramayn. Second, some Malays went to $\mathrm{H}$ \{aramayn after graduating from local pondok/pesantren/suran to learn more about Islam from specialized 'ulama'. During this period they also studied the political situation in the Middle East, especially in Haramayn, Egypt and Turkey. Third, many 'ulamās also produced newspapers or magazines to dissiminate their reformist ideas in the Archipelago, such as Seruan Al-Azhar, Pilehan Timoer, Idaran Zaman, Pengasoh, al-Ikhwan, and alImâm. ${ }^{14}$ In sum, the early twentieth century was the period when Islamic reformism began to spread widely across the Indonesian Archipelago. Based on the reformist ideas of the Cairo 'ulamā, Indonesian Muslims engaged in the project of purifying Muslims' religious practices and voicing the need to reformulate Islamic doctrines in the light of the modern spirit of progress. ${ }^{15}$

The third phase of Islamic thought in Southeast Asia began when Orientalists from Western countries conducted research on Islam motivated by both purely academic and colonial interests. They have played an important role in Islamic Studies in Southeast Asia. Historically, the coming of the Orientalists to Southeast Asia can be divided into three periods. Initially they came as travelers, writing reports on the situation of the Islamic communities in the region. ${ }^{16}$

14 On this, see generally Othman, Islam Dan Masyarakat Melayu: Peranan Timur Tengah, pp. 109-67; William Roff, "Indonesian and Malay Students in Cairo in the 1920's," Indonesia 9 (1970), pp. 73-87.

15 Jajat Burhanuddin, "The Fragmentation of Religious Authority: Islamic Print Media in Early 20th Century Indonesia," Studia Islamika 11, no. 1 (2004), p. 27. See also Charles Kurzman, "Introduction: The Modernist Islamic Movement," in Charles Kurzman (ed.), Modernist Islam, 1840-1940: A Sourcebook (Oxford: Oxford University Press, 2002), pp. 3-27; Riddel, Islam and the Malay-Indonesian World: Transmission and Responses, pp. 207-15; William Roff, The Origins of Malay Nationalism (New Have: Yale University Press., 1967), pp. 56-67; William Roff, "Kaum Muda-Kaum Tua: Innovation and Reaction Amongst the Malays, 1900-41," in Ahmad Ibrahim, Sharon Siddique, and Yasmin Hussain (eds), Readings on Islam in Southeast Asia (Singapore: ISEAS, 1986), pp. 123-9.

16 See Anthony Reid, "Completing the Circle: Southeast Asian Studies in Southeast Asia," in ARI Working Paper (Singapore: ARI, 2003), pp. 1-3. 
Many of their reports have become important sources for our knowledge about the situation of Muslims in Southeast Asia at this time. Second, they arrived in Southeast Asia as part of colonial missions. In this phase, the Dutch scholar C.S Snouck Hurgronje played a critical role in Islamic studies during his sojourns in Indonesia and Makkah in the late nineteenth and early twentieth centuries. ${ }^{17}$ The other scholar who has had a key influence was an American anthropologist, Clifford Geertz. Based on his research at Modjukuto, Central Java, in the 1950s, Geertz developed a typology in which Muslim society in Indonesia was seen as divided into three groups, santri, abangan, and priyayi. ${ }^{18}$ Geertz's scheme of classification exerted great influence on scholars, both Indonesian and non-Indonesian, who attempted to describe Muslim society based on their socio-politico outlook. ${ }^{19}$ Benedict Anderson remarks that political scientists largely adopted Geertz's framework but often utilized it in a subtly selective way. By treating the three aliran (lit. "streams") as parallel vertical pyramids they frequently overlooked or underestimated the power relation between them..$^{20}$ The third phase of the Orientalist influence on Islamic Studies in Southeast Asia has been the development of the field of Asian or Southeast Asia Studies in Western universities, which included the study of Muslims in the region.

The latest phase in Islamic Studies has arisen when Southeast Asian scholars began to produce their own interpretations of Islam, starting from early years after independence until the present. This group was certainly influenced by the thinking of Western countries, in particular the United States, Canada, the Netherlands, Germany, and

17 See Benda, "Christian Snouck Hurgronje and the Foundations of Dutch Islamic Policy in Indonesia," pp. 338-47.

18 See Clifford Geertz, The Religion of Java (Chicago and London: The University of Chicago Press, 1960); Clifford Geertz, "The Religion of Java," in Ibrahim, Readings on Islam, pp. 271-8; Bahtiar Effendy, "What Is Political Islam? An Examination of Its Theoretical Mapping in Modern Indonesia, " in Chaider S. Bamualim (ed.), A Portrait of Contemporary Indonesian Islam, (Jakarta: CLS and KAS, 2005), pp. 9-15.

${ }^{19}$ See M. Bambang Pranowo, "From Aliran to Liberal Islam: Remapping Indonesian Islam," in Bamualim (ed.), A Portrait of Contemporary Indonesian Islam, pp. 27-34; Fred Inglis, Clifford Geertz: Culture, Customs and Ethics (Cambridge: Polity Press, 2000).

${ }^{20}$ Benedict O'Gorman Anderson, "Perspective and Method in American Research on Indonesia," in Benedict Anderson and Audrey Kahin (eds), Interpreting Indonesian Politics: Thirteen Contribution to the Debate (New York: Cornell University, 1982), p. 78. 
Australia, which offered scholarships to Southeast Asian scholars to study Islamic Studies or Muslim societies in these countries. In this context John L. Esposito and John O. Voll argue that,

As a part of the interaction with the West and the consequent Westernization and modernization of significant sectors in Muslim societies, a grouping (or "class") of "secular intellectuals" emerged. These people were similar to, and possibly both inspired and created by, their counterparts in the evolving modern societies of Western Europe and North America. ${ }^{21}$

In Islamic Studies discourse this group could be described as "modernist", "neo-modernist", "secularist", "liberal", and "posttraditionalist". In fact, this terminology does not derive from "indigenous" discourse in Islamic studies (diräsab Islamìyah) but rather from the social sciences developed by Western scholars. Modernist scholars tend to go back to the Qur'an and Sunnah and develop interpretations that are adapted to the modern era. In this group Riddel lists scholars such as Harun Nasution, S.M.N Al-Attas, Nurcholish Madjid, Anwar Ibrahim, Hasbullah Bakry, Djarnawi Hadikusuma, Abdurrahman Wahid, Amien Rais, and Chandra Muzaffar. ${ }^{22}$ Furthermore, he has categorized Nasution and Madjid as neomodernists, and Rais as a modernist. ${ }^{23}$ Charles Kurzman lists a number of other figures whom he regards as modernists, including Achmad Dahlan, Syeikh Ahmad Surkati, Agus Salim, Ahmad Hassan, and Hasyim Asy'ari. ${ }^{24}$ For Kurzman, the modernist movement was "the self-conscious adoption of "modern" values [...] associated with the modern world, especially rationality, science, constitutionalism, and certain forms of human equality. Thus this movement was not simply "modern" (a feature of modernity) but also "modernist" (a proponent of modernity)." 25

\footnotetext{
${ }^{21}$ John L. Esposito and John O. Voll, Makers of Contemporary Islam (Oxford: Oxford University Press, 2001), p. 12. For the origin of this group see also Howard M. Federspiel, "Muslim Intellectual in Southeast Asia," Studia Islamika 6, 1 (1999), pp. 41 76.

22 Riddel, Islam and the Malay-Indonesian World: Transmission and Responses, pp. 231-58.

${ }^{23}$ Riddel, "Schools of Islamic Thought in Southeast Asia," pp. 12-15.

${ }^{24}$ Charles Kurzman, "Introduction: The Modernist Islamic Movement."

25 Ibid., p. 4.
} 
The term "neo-modernist", first proposed by Fazlur Rahman of Chicago University, has been promoted in the study of Southeast Asian Islam by Greg Barton of Deakin University in his Ph.D. dissertation on Islam in Indonesia. ${ }^{26} \mathrm{He}$ characterizes the outlook of scholars in this movement as combining classical Islamic scholarship with modern, or Western, analytical methods. They have enjoyed the benefit of both a classical or traditional Islamic education revolving around the study of the Qur'an and classical Arabic texts, and a modern Western-style education. ${ }^{27}$ According to Barton, this kind of Islamic thought is represented by figures such as Madjid, Djohan Effendi, Ahmad Wahib, and Wahid. ${ }^{28}$ For Riddel Islamic neomodernists:

... tend not to see Islam through the lens of shari'ah law, but rather in terms of universal values. These values need to be agreed by non-Muslim as well as Muslims, in the view of the neo-modernist. [...] Neo-modernists are more inclined towards a Western-style democracy than other Muslim groups, and their public discourse gives greater emphasis to human rights and women's rights $[\ldots]$ the neomodernists consider that the Qur'an and Sunnah should be open to new and evolving interpretations [...] the neomodernists are more concerned with the essence of Islamic teaching than its form. [...] Neo-modernists are more positively disposed to Western liberal thought; they prioritise social and economic interests over political power and they cooperate with secular groups. ${ }^{29}$

The issue of secularism in Islamic thought, that is, the attempt to separate Islam and politics, is a vexed one. Mohammed Arkoun has

\footnotetext{
${ }^{26}$ See generally Greg Barton, "Neo-Modernisme: A Vital Synthesis of Traditionalist and Modernist Islamic Thought in Indonesia," Studia Islamika 2, 3 (1995), pp. 1-75; Greg Barton, "Indonesia's Nurcholish Madjid and Abdurrahman Wahid as Intellectual Ulama: The Meeting of Islamic Traditionalism and Modernist in Neo-Modernist Thought," Islam and Christian-Muslim 8, 3 (1997), pp. 337-42; Greg Barton, Gagasan Islam Liberal di Indonesia: Pemikiran Neo-Modernisme Nurcholish Madjid, Djohan Effendi, Ahmad Wabib, Dan Abdurrahman Wabid (Jakarta: Paramadina, 1999).

27 Barton, "Neo-Modernisme: A Vital Synthesis of Traditionalist and Modernist Islamic Thought in Indonesia," P. 7.

${ }^{28}$ See also Malcom Cone, "Neo-Modern Islam in Suharto's Indonesia," New Zealand Journal of Asian Studies 4, no. 2 (2002), pp. 52-67.

${ }^{29}$ Riddel, "Schools of Islamic Thought in Southeast Asia," p. 12.
} 
attempted to theorize the problem of secular thought in Islam. He specifically argues that (1) Secularism is included in the Qur'an and the Medinan experience; (2) The Umayyad and Abbasid states can also be regarded as secularist; (3) Military power played a very early and prominent role in the Caliphate, the Sultanate, and all later so-called "Islamic" forms of government; (4) Attempts to rationalize de facto secularism and to develop a secular attitude were made by the falsifah [Muslim philosophers]; (5) So-called "orthodox" expressions of Islam are in fact arbitrary selections and ideological uses of beliefs and ideas and practices perceived as authentically religious; (6) The whole status of the religious, of the sacred, and of revelation, has to be reexamined in light of a modern theory of knowledge; (7) All political regimes which have appeared in Islamic societies following their liberation from colonialism are de facto "secular", dominated by Western models, cut off from the classical theory of authority as well as from intellectual modernity; (8) .... laicité as a source and space of intellectual freedom to initiate a new theory and practice of authority, is a work also to be undertaken in Western societies today. ${ }^{30}$

In Islamic Studies, those who challenge the accepted role of Islam in society may be called "secularists". This group tends to be regarded as always opposed to the fundamentalists (or "radicals", "Islamists", "Salafists", and "terrorists"). In fact, those outside hard-line Islamic movements, including modernists, neo-modernists, liberals, and posttraditionalists are often considered "secularists" in the minds of the fundamentalists. ${ }^{31}$

Islamic thought in Southeast Asia can thus be divided into different phases, with each phase preoccupied by different concerns. In the first phase most thinkers tried to solve the problems of Muslims in daily life and save them from what they regarded as the dangers of Sufism. Although this current of thought was seen as reformism at the time, its concerns were quite different to the problems that concerned the reformists of the nineteenth and twentieth centuries - for instance colonialism, the backwardness of Muslims in education, and the

\footnotetext{
30 See Mohammed Arkoun, "The Concept of Authority in Islamic Thought: La Hukma Illa Lillah," in C.E. Boswirth, et al (eds), The Islamic World: From Classical to Modern Times (Darwin: The Darwin Press, 1989), pp. 50-1.

31 Generally, see Hartono Ahmad Jaiz, Ada Pemurtadan Di LAIN (Jakarta: Al-Kautsar, 2005).
} 
problem of modernization. The reformism of the nineteenth and twentieth centuries was a movement developed by 'ulamà' and influenced by Middle Eastern scholars. Modernization in Islamic thought in the late-nineteenth century was quite different again from the modernization of the twentieth century. This latter period saw the rise of Muslim intellectuals and the decline of the traditional 'ulama' in Southeast Asia. This new group enjoys good relations with Muslim intellectuals around the world as well as with Western scholars. Finally, Islamic thought in the twentieth century has been dominated by social and political concerns. ${ }^{32}$

\section{Islam Liberal;}

\section{From a Textual to a Contextual approach in Islamic Studies}

The term Islam Liberal is not traditionally found in Islamic scholarship. Historically, however, liberal thinking in Islam can be said to have first surfaced in religious discourse in philosophy and subsequently in Sufism. ${ }^{33}$ Most thinkers in Islam who may be categorized as "liberal" were philosophers, such as Ibn Rusyd (11261197), ${ }^{34}$ the author of Bidayat al-Mujtabid, a book discusses on the comparative perspective of Islamic jurist on Islamic law. The relationship between reason and revelation has represented a very serious issue in Islamic philosophy and theology. The school of Mu'tazilah appears liberal and rational compared to other Islamic theological schools. The Mu'tazilah school took the stance that human reason is able to recognize God. ${ }^{35}$

Liberal thought gained ground among Muslim thinkers in the twentieth century. ${ }^{36}$ In his books Liberal Islam (1998) and Modernist

\footnotetext{
32 Richard C. Martin, Islamic Studies: A History of Religious Approach (New Jersey: Prentice Hall: Prentice Hall, 1996), p. 239.

${ }^{33}$ Komaruddin Hidayat, "Contemporary Liberal Islam in Indonesia, Pluralism, and the Secular State," in Bamualim (ed.), A Portrait of Contemporary Indonesian Islam, p. 54.

34 On Ibn Rusyd see Enest Wolf-Gazo, "Contextualizing Averroes within the German Hermeneutic Tradition," Alif: Journal of Comparative Poetics 16 (1996), p. 133163.

35 Saiful Muzani, "Mu'tazilah Theology and the Modernization of the Indonesian Muslim Community: Intellectual Portrait of Harun Nasution," Studia Islamika 1, 1 (1994), p. 113.

${ }^{36}$ Charles Kurzman, "Liberal Islam: Prospects and Challenges," Middle East Review of International Affairs 2, no. 2 (1999), p. 11-9.
} 
Islam (2002) Charles Kurzman tries to trace the roots of liberal Islam. According to Kurzman, every region of the Islamic world has witnessed parallel debates over the past two centuries between three traditions of socio-religious interpretation. The first tradition may be called customary Islam, characterized by the combination of regional practices and those that are shared throughout the Islamic world. The second tradition is revivalist Islam, also known variously as Islamism, fundamentalism, or Wahhabism. The third is liberal Islam, which defines itself in contrast to customary traditions and calls upon the precedent of the early period of Islam in order to de-legitimize present-day practices. ${ }^{37}$

The secularization of Muslim society is among key issues for scholars of liberal Islam. In Indonesia, the fierce debate about the merits of separating Islam and State came to a head following the declaration of independence of August 17 1945, in which the secularists were represented by Soekarno and the Islamists by Mohammad Natsir. ${ }^{38}$ At that time the secularists were able to win the elections and the debates in parliament. It is not difficult to understand why the controversy about secularization, especially whether Islam should be the sole basis of Indonesia, should continue until today. ${ }^{39} \mathrm{At}$ independence the Islamic faction in Indonesian politics was divided into two groups. The first group agreed to join the government while continuing to argue the case for Islam to be instituted as the basis of the state of Indonesia. The second group rejected the government and proceeded to carry out a rebellion in West Java, Sulawesi, and Aceh, known as DI/TII (Darul Islam/Tentara Islam Indonesia or "Islamic State/Indonesia Islamic Force"). The aim of this group was the implementation of an Islamic state and Islamic law in Indonesia. By

37 Charles Kurzman, "Introduction: Liberal Islam and Its Islamic Context," in Kurzman (ed.), Liberal Islam, pp. 5-6.

38 Saifuddin Anshari, "Islam or the Panca Sila as the Basis of the State," in Ahmad Ibrahim, Sharon Siddique, and Yasmin Hussain (eds.), Readings on Islam in Southeast Asia (Singapore: ISEAS, 1985), pp. 221-228; Bahtiar Effendy, Islam and the State in Indonesia (Singapore: ISEAS, 2003), pp. 33-44; Kamaruzzaman Bustamam-Ahmad, Wajah Baru Islam di Indonesia, pp. 251-276.

${ }^{39}$ See Ahmad Bunyan Wahib, "Save Indonesian by and from Shari" a: A Debate on the implementation of Shari'a," Al-Jâmi'ab: Journal of Islamic Studies, Vol. 42, No. 2 (2004): pp. 319-341; Jamhari, "Fundamentalism and the Implementation of Shari" a," in Bamualim (ed.), A Portrait of Contemporary Indonesian Islam, pp. 67-76. 
the early 1960s, however, the DI movement had effectively ended after all of its leaders had either been arrested or killed. ${ }^{40}$

Following the return of Nasution and Madjid from their studies at Western universities, liberal Islam began to receive serious attention among Islamic scholars in Southeast Asia. Nasution was one of the most influential scholars in promoting liberal thinking in Indonesia in 1970s. After graduating from McGill University with a dissertation on Muhammad 'Abduh's theological thought, he taught at IAIN (State Institute of Islamic Studies). He argued that Indonesian Muslims were less developed in economic and cultural terms because they were generally theologically fatalistic and static. The theology of Ahl alSunnah or Ash'ariyyah, for him, seemed to be the primary source responsible for this state of stagnation and underdevelopment. ${ }^{41}$ In the area of Islamic law Indonesians adhere to the Syafíi school; in theology they affiliate themselves with Asy'ari, and in terms of moral conduct they follow Imâm al-Ghazzali. Nasution regarded this model of religious interpretation as narrow-minded, therefore an openness to Islamic reformism or modernism was a prerequisite for the development of the ummah. Nasution desired to replace the fatalistic or traditional world view (theology) of the ummah with one that is more dynamic, rational, and modern. ${ }^{42}$ To solve this problem, Nasution began to change the paradigm of teaching Islamic studies at IAIN. He proposed subjects that had never before been considered at IAIN, including Introduction to Islamic Studies, Philosophy, Islamic Mysticism or Sufism (Tasamwuf), Islamic Theology (Kalam), Sociology, and Research Methodology. ${ }^{43}$

Madjid was the other scholar who played a critical role in promoting liberal thought in Indonesia. He became an icon of Islamic thought Indonesia when he introduced the phrase: "Islam Yes, Partai Islam No!" (Islam Yes, Islamic Parties No!). Using such rhetoric, he encouraged his fellow Muslims to direct their commitment to Islamic values rather than institutions, even those with an Islamic basis such as

\footnotetext{
${ }^{40}$ Jamhari, "Fundamentalism and the Implementation of Shari"a," p. 8.

${ }^{41}$ Muzani, "Mu'tazilah Theology," pp. 101-2.

42 Muzani, "Mu'tazilah Theology," p. 102; Bahtiar Effendy, Islam and the State in Indonesia, (Singapore: ISEAS, 2003), pp. 75-76.

${ }^{43}$ Muzani, "Mu'tazilah Theology," p. 103.
} 
Islamic parties. ${ }^{44}$ About his controversial address on January 2, 1970, when he made his controversial appeal, Madjid wrote,

... I made this presentation because I expected a special, closed meeting with free discussion among the leaders of four young Muslim organizations. There was a strong reaction against my use of such controversial terms as "secularization," "desacralization," "liberalization," "socialism"... I was quite aware of the danger of publicity referring to these points. ... Some of my adversaries suggested that I "repent" and apologize to the Muslim community. This I could hardly have done. Despite my knowledge that the approach was wrong, I firmly believed that the purpose was right. ${ }^{45}$

Besides Nasution and Madjid, there are a number of other highprofile Muslim thinkers in Indonesia who can be categorized as liberal, including former President and former head of NU Wahid, as well as Wahib, and Munawir Sjadzali. Wahid, for example, advocated that the notions of Islam were a complementary factor in Indonesia's sociocultural and political life and the indigenization of Islam (pribumisasi Islam). ${ }^{46}$ Wahib is a controversial Muslim thinker who has promoted ideas about the freedom of thought, modernity and renewal, and contextual ijtibäd. ${ }^{77}$ Munawir Sjadzali, an ex-Minister of Religious Affairs during the Soeharto regime, promoted the issue of the reactualization of Islamic teaching in Indonesia, especially in Islamic Inheritance Law in Indonesia. He has advocated the total equalization of inheritance rights of male and female children. ${ }^{48}$

\footnotetext{
${ }^{44}$ Bahtiar Effendy, Islam and the State in Indonesia, p. 75.

45 Nurcholish Madjid, "The Issue of Modernization among Muslims in Indonesia: from a Participant's Point of View," in Ahmad Ibrahim, Sharon Siddique, and Yasmin Hussain (eds.), Readings on Islam in Southeast Asia (Singapore: ISEAS, 1985), p. 384. See also Barton, "Neo-Modernisme: A Vital Synthesis of Traditionalist and Modernist Islamic Thought in Indonesia," p. 19.

${ }^{46}$ Effendy, Islam and the State in Indonesia, p. 76.

47 Barton, "Neo-Modernisme: A Vital Synthesis of Traditionalist and Modernist Islamic Thought in Indonesia," pp. 34-45.

48 See generally Munawir Sjadzali, Ijtihad Kemanusiaan (Jakarta: Paramadina, 1997); Muhammad Wahyuni Nafis et al, Kontektualisasi Ajaran Islam: 70 Tabun Prof. Dr. H. Munawir Sjadzali (Jakarta: Paramadina, 1995).
} 
Mention should also be made of the Islam Liberal network in Indonesia founded by young Muslims in Jakarta. Historically speaking, this group originated out of informal meetings of young Muslim activists responding to contemporary issues in Indonesia, especially the growth of radical Islamic movements. These activists include Luthfi Assyaukanie (lecturer at Paramadina University who completed his Ph.D in Islamic Studies at the University of Melbourne), Ulil AbsharAbdalla (a columnist with an NU background who received a Fulbright Scholarship to pursue graduate studies at Boston and later began a $\mathrm{PhD}$ at Harvard University), Ahmad Sahal (a columnist with a NU background), Farid Gaban (ex-journalist), Hamid Basyaib (a researcher at Aksara Foundation), and Deny J. A. (a lecturer at Jayabaya University). In March 2002 they established the Liberal Islam Network (Jaringan Islam Liberal) to disseminate their views through the media. An active website has been established (www.islamlib.com). In a moderated internet chat group called islamliberal@yahoogroups.com they debate issues, respond to questions and views, cite the Qur'an to support their arguments and provoke debates with their critics. ${ }^{49}$

The young liberal Islamic groups trace their intellectual origins to many sources. Previously this kind of Islamic thought has been promoted by the older generation of intellectuals, such as Nasution, Madjid, Effendi, Wahib, Wahid, Dawam Rahardjo, and Masdar F. Mas'udi. These thinkers separated Islam from the political and social situation in Indonesia during the New Order era. The main issues at that time were pluralism, culturalism, inclusivism, modernism, and pribumisasi among Muslims in Indonesia. ${ }^{50}$ They tended to see Islam not through the lens of shari'ah law but rather in terms of universal values. ${ }^{51}$

\footnotetext{
49 Barry Desker, "Islam and Society in Southeast Asia After September 11," Institute of Defence and Strategic Studies, Working Paper, No. 33, p. 6.

50 See generally Barton, "Indonesia's Nurcholish Madjid and Abdurrahman Wahid as Intellectual Ulama: The Meeting of Islamic Traditionalism and Modernist in NeoModernist Thought," pp. 337-342: Greg Barton, Gagasan Islam Liberal Di Indonesia: Pemikiran Neo-Modernisme Nurcholish Madjid, Djoban Effendi, Ahmad Wabib, Dan Abdurrabman Wabid. Fauzan Saleh, Modern Trends in Islamic Theological in Twentiethcentruy Indonesia: A Critical Survey (Leiden: Brill, 2001).

${ }^{51}$ Riddell, "Schools of Islamic Thought in Southeast Asia," p. 12.
} 
I have argued elsewhere ${ }^{52}$ that at least seven factors are responsible for the liberal outlook of the young generation of Indonesia Muslims. First, the pesantren is their intellectual foundation. They are familiar with the classical texts (kitab kuning) and Islamic methodology (usül alfiqb). This education has helped them to develop into critical scholars following their graduation from the pesantren, especially those with a NU background. Many prominent Muslim thinkers in Indonesia, including Madjid and Wahid, graduated from pesantren. Second, many young Islamic scholars have been involved in NGO activities, especially in Jakarta and Yogyakarta. Among the members of Islam Liberal and its allies there are numerous NGO workers who are supported by international funding, for example, the Asia Foundation and the Ford Foundation. Third, there is an intellectual network of students who have graduated from Egypt. Many of the younger generation of Indonesian Muslims have learned about contemporary developments in Islam from Egypt. ${ }^{53}$

Fourth, they tend to become liberal because of the Islamic education model in IAIN. Ironically, one of the main reasons why they become liberal when studying at IAIN is that "they do not learn in depth about Islamic studies." 54 Ken Miichi writes that this youngest generation of NU cadres with an IAIN education inherited the ideas of the leftist intellectual network and formed an Islamic left, working with non-religious and leftist social movements. They have read everything from Marx to Gramsci to Foucault, while in their discussions of Islam they often refer to Western-educated Muslim intellectuals such as Hasan Hanafi and Mohammed Arkoun. ${ }^{55}$ Fifth, they have been influenced by liberal Muslim thinkers from the Middle East with a Western education such as Fazlur Rahman, Abdullahi Ahmad AnNaim, Mohammad Arkoun, Nasir Hamid Abu Zayd, Abdul Karim Souroush, Ali Harb, Amina Wadud, Fatima Mernissi, and Muhammad

52 See Kamaruzzaman Bustamam-Ahmad, Islam Historis: Dinamika Studi Islam di Indonesia (Yogyakarta: Galang Press, 2002), pp. 65-82.

53 See Arsyad Hidayat, "Mencari Islâm Alternatif; Pengalaman Seorang Mahasiswa alAzhar," Tashwirul Afkar, No. 8 (2000), pp. 72-88; Zuhairi Misrawi, "Pemikiran Islam Kontemporer di Mesir: Sebuah Pergolakan dari Eksklusivisme Menuju Inklusivisme," Tashwirul Afkar, No. 8 (2000), pp. 4-28.

${ }^{54}$ See Bustamam-Ahmad, Islam Historis. Especially chapter I.

55 Ken Miichi, "Islamic Youth Movements in Indonesia," ILAS Newsletter 32 (November 2003), p. 22. 
Syahrur. They have translated these Islamic scholars' works into Bahasa Indonesia and have sometimes invited them to give informal lectures at their base camp. Sixth, Indonesianists have played a significant role in educating their members through both formal and informal lessons. Some young Islam Liberal scholars have a close relationship with prominent Indonesianists such as Daniel S. Lev and William B. Liddle. Of course, most, if not all, Indonesianists are supporters of Islam Liberal in Indonesia. ${ }^{56}$ Seventh, one cannot underestimate the factor of Wahid as the leading Muslim thinker in Indonesia up until his recent death. It is undeniable that Abdurrahman played important role in Islamic discourse and became an umbrella for the Islamic younger generation, especially those with an NU affiliation.

According to its website, Islam Liberal offers a new interpretation of Islam as a religion based on a number of insights. ${ }^{57}$ The first is the openness of the gates of ijtihad in every aspect. The second is its emphasis on the ethical-religious spirit, not the literal meaning of the text. The third is the acceptance of a relative, open, and plural truth. The fourth is its stand alongside minorities and the oppressed. The fifth is its affirmation of freedom of belief and faith. The sixth is the separation of ukhrawi (heavenly) and duniawi (worldly) authority, and religious and political authority.

Again, these specific issues do not constitute "a new interpretation" among Muslim scholars in Indonesia. A number of Muslim thinkers in Indonesia have previously discussed the issue of reopening the gates of ijtihad, such as Hazairin with his "National Mazhab", Hasbi Ash-Shiddieqy with "Fiqh Indonesia", Munawir Sjadzali with his "re-actualisation of Islamic law", and Sahal Mahfud with his "Social Fiqh". Furthermore, the term "ethical-religious spirit" had been promoted by Mukti Ali in religious studies among Islamic scholars in Indonesia through his course on Comparative Religion at IAIN, inspired by the work of Jaachim Wach. ${ }^{58}$ By the 1990 s this issue

\footnotetext{
56 See M. A. Fattah Santoso, "Fenomena Jaringan Islam Liberal (JIL) Sebuah Studi Pendahuluan,“ Profetika, Vol. 5, No. 2 (July 2003), p. 158; Kamaruzzaman Wajah Baru Islam di Indonesia, pp. 60-61.

${ }^{57}$ Jaringan Islam Liberal, http://islamlib.com/en/aboutus.php, accessed 29 August 2005.

${ }^{58}$ See Joachim Wach, The Comparative Study of Religions. Edited by J. M. Kitagawa. (New York: Columbia University Press, 1958).
} 
had also been endorsed by the Rector of UIN (State Islamic University) of Sunan Kalijaga, M. Amin Abdullah, a member of Muhammadiyah, in some of his works. ${ }^{59}$ His work is not as widely known since his publications do not appear in the national daily newspapers such as Kompas, Media Indonesia, and Republika. The subject of pluralism was also promoted by Madjid ${ }^{60}$ and Wahid ${ }^{61}$ during the Soeharto and Reformasi periods. Likewise the issue of secularization in Indonesia has been the subject of debate among Muslims since before Independence, in particular in the fierce debates between Soekarno and Mohammad Natsir. ${ }^{62}$

According to the JIL website the reason why the group has adopted the name Islam Liberal is because,

The name "Liberal Islam" illustrates our fundamental principles; Islam which emphasizes "private liberties" (according to Mu'tazilah's doctrine regarding "human liberties"), and "liberation" of the socio-political structure from unhealthy and oppressing domination. The "liberal" adjective has two meanings: "liberty" (being liberal) and "liberating". Please note that we do not believe in Islam as such - Islam without any adjective, as some people argued. Islam is impossible without an adjective; in fact Islam has been interpreted in so many different ways in accordance

\footnotetext{
59 See M. Amin Abdullah, "Al-Ta'wī Al-'Ilmī: Ke Arah Perubahan Paradigma Penafsiran Kitab Suci," Al-Jâmi'ab: Journal of Islamic Studies 39, 2 (2001); M. Amin Abdullah, Dinamika Islam Kultural: Pemetaan Atas Wacana Keislaman Kontemporer, ed. M. Muchlas Rowi, Hilman Latief, and Asep P.B. (Bandung: Mizan, 2000); M. Amin Abdullah, Falsafah Kalam Di Era Postmodernisme, ed. Muh. Sungaidi Ardani (Yogyakarta: Pustaka Pelajar, 1995); M. Amin Abdullah, "Kajian Ilmu Kalam Di Iain Menyongsong Perguliran Paradigma Keilmuan Keislaman Pada Era Milenium Ketiga," Al-Jâmi'ab: Journal of Islamic Studies 65, 6 (2000); M. Amin Abdullah, "New Horizons of Islamic Studies through Socio-Cultural Hermeneutics," Al-Jâmi' ab: Journal of Islamic Studies 41, 1 (2003); M. Amin Abdullah, "Preliminary Remarks on the Philosophy of Islamic Religious Science," Al-Jâmi'ab: Journal of Islamic Studies 61 (1998); M. Amin Abdullah, Studi Agama: Normativitas Atau Historisitas?, ed. Muh. Sungaidi Ardani (Yogyakarta: Pustaka Pelajar, 1996); M. Amin Abdullah, "Telaah Hermenetis Terhadap Masyarakat Muslim Indonesia," in Kontektualisasi Ajaran Islam: 70 Tabun Prof. Dr. H. Munawir Sjadzali, Ma, ed. Muhammad Wahyuni Nafis, et al. (Jakarta: Paramadina, 1995).

${ }^{60}$ Madjid, "Islamic Roots of Modern Pluralism: Indonesian Experiences," pp. 55-77.

${ }^{61}$ Abdurrahman Wahid, Prisma Pemikiran Gus Dur (Yogyakarta: LKiS, 1999).

${ }^{62}$ See Kamaruzzaman Bustamam-Ahmad, Relasi Islam dan Negara (Magelang: Indonesia Tera 2001).
} 
to the interpreter's needs. We have chosen a genre of interpretation, and by this way, we selected an adjective for Islam, it is "liberal". 63

The Islam Liberal group appears to have adopted the methodology of the Mu'tazilah in their mission to make 'aql (intellect) dominant over waby (revelation). That is, their arguments are based on logic rather than Islamic revelation.

It could be argued that this latest manifestation of Islam Liberal in Indonesia is in fact a response to the recent rise of radical Islamic movements and their demands to establish an Islamic state in Indonesia and to enforce Islamic law, increased anti-Americanism, and other controversial issues in Islamic discourse such as the position of the Qur'an and the Hadith, marriage between Muslims and nonMuslims, gender issues and secularization. Ulil admits to being frequently accused of being an ally of the Americans, a CIA agent, and of having unlimited access to American money. ${ }^{64}$ In fact, many Islam Liberal projects are indeed funded by international agencies and, and they have been entrapped in the "be careful" academic environment post 9/11.65 Since the emergence of Jaringan Islam Liberal an on-going debate has developed between supporters of Islam Liberal including JIL and some young Islamic scholars from Muhammadiyah and NU - and "Islam Literal" (Literal Islâm) organizations such as Lasykar Jihad, Front Pembela Islam, Partai Keadilan, Dewan Dakwah Islamiyah Indonesian, and Majelis Mujahidin. Barry Desker points out that the debate between Muslim fundamentalists and the liberals in Indonesia mirrors similar debates between Christian fundamentalists and liberals in the West. ${ }^{66}$ For instance, Media Dakwah of Dewan Dakwah Islamiyyah

\footnotetext{
${ }^{63}$ Jaringan Islam Liberal, http://islamlib.com/en/aboutus.php

${ }^{64}$ Zainah Anwar and Ulil Abshar-Abdalla, "Political and Security Outlook 2003: Islâm: The Challenge from Extremist Interpretations," in Trends in Southeast Asia Series 4 (Singapore: ISEAS, 2003), p.18.

${ }^{65}$ Beshare Doumani listed the following eight "be carefuls" for Muslim scholars: be careful what you buy or borrow from the library; be careful what readings you assign in your classes; be careful what you teach; be careful what you say in class or offcampus; be careful you if apply for funding from the Ford or Rockefeller Foundations; be careful if you criticize Israeli government policies; and be careful if you are a nonUS citizen who is going to the U.S. to teach or study; See Beshara Doumani, "Be Careful What You Say on Campus", A Seattle Post-Intelligencer (April 2, 2004) http://history.berkeley.edu/faculty/Doumani/academic freedom.pdf

${ }^{66}$ Barry Desker, "Islam and Society,” p. 10.
} 
Indonesian publications, accuses JIL of promoting an evil logic, of being a form of terrorism, of being dangerous for Islam, of destroying Islamic theology, of being Orientalists and secularists, as well as being anti-dialogue. Fundamentalist groups debate the Islam Liberal activists in open public forums. Sometimes the debate is not about the main topic but rather a "battle of ayats," "the yellow books", and "the voices of "ulama' from the fundamentalist front." In one debate held in Yogyakarta, many of the participants accused Ulil and his friends of no longer being Muslims, but kafir (infidels). Ironically, these statements came from scholars studying at secular universities, rather than from the Islam-based IAINs or the pesantren students. ${ }^{67}$ Fundamentalist groups in Indonesia often appear to be based at and find their inspiration from the secular universities.

\section{Islam Hadhari;}

\section{The Politics of "Islamic Civilization" in Malaysia}

Since independence, politics in Malaysia has been dominated by the Malays. ${ }^{68}$ When we speak of the Malays, it is difficult to avoid discussing the place of Islam in Malaysia, both politically and sociologically. The politicization of Islam has become a key factor in the Malaysian political terrain in recent years. It has found perhaps clearest expression in the so-called "Islamization race" between the ruling party, the United Malays National Organization (UMNO), and the opposition Parti Islam Se-Malaysia (PAS). ${ }^{69}$ Political Islam has manifested great intra-communal tensions within the Malay community. As the two Malay political parties battle for political

${ }^{67}$ On this phenomena, see Kuntowijoyo, Muslim Tanpa Masjid: Esai-Esai Agama, Budaya, Dan Politik. Dalam Bingkai Strukturalisme Transendental (Bandung: Mizan, 2001).

68 On this see Timothy P. Barnard, ed., Contesting Malayness: Malay Identity across Boundaries (Singapore: Singapore University Press, 2006). See also Joel S. Kahn, Other Malays: Nationalism and Cosmopolitanism in the Modern Malay World (Singapore: Singapore University Press, 2006). Anthony Milner, The Invention of Politics in Colonial Malaya: Contesting Nationalism and the Expansion of the Public Sphere (Cambridge: Cambridge University Press, 1995). Cheah Boon Kheng, Malaysia: The Making of a Nation (Singapore: ISEAS, 2002). Khoo Kay Kim, Malay Society Transformation \& Democratisation: A Stimulating and Discerning Study of the Evolution of Malay Society, 3 ed. (Selangor: Pelanduk, 2001).

${ }^{69}$ Joseph Liow, “Deconstructing Political Islam in Malaysia: Umno's Response to Pas' Religio-Political Dialectic," in Working Paper (Singapore: Institute of Defence and Strategis Studies, 2003), p. ii. 
legitimacy and electoral support, the resulting competition has led to efforts to institutionalize Islam and expand the religious bureaucracy, thereby sharpening the debate over what Islam means in Malaysia and how it should be practiced. 70

There are two problems in attempting to situate the place of Islam in Malaysia. The first is the question of the relationship between Islam and the state, which, because it has never been satisfactorily resolved by Muslim thinkers, continues to play a vital role in the ongoing debate. The second is the shift in the meaning of Islamic debates that tend to adopt a perspective that is too focused on Islam as a unifying political and social force. ${ }^{71}$

The most representative Islamic figures in Malaysia are from the Malay parties, UMNO and PAS. The political struggle between these two parties has had serious consequences for the implementation of Islamic teachings in Malaysia. PAS provides an interesting example with its attempt at constructing and enforcing a system of "Islamic democracy" in the two east coast states of Kelantan and Terengganu. ${ }^{72}$ Driven by the global resurgence of Islamic consciousness and strengthened by the enthusiasm of the new guard, epitomized by figures such as Fadzil Noor, Abdul Hadi Awang, and Nakhaie Ahmad, a rejuvenated PAS began pushing a more deliberate Islamic agenda in Malaysia as a political tactic to whittle away support for UMNO. ${ }^{73}$ In UMNO there has also been much debate about the role of Islam in modern Malaysia. Basically, the roots of the controversy involve the question of how to bring Malaysia into the modern era with an Islamic coloring. But the real debate has been over the interpretation of the shari'ah, especially after Anwar Ibrahim joined the party in 1982. Since his days as leader of ABIM Anwar rationalized the theme of struggle for socio-economic justice with the ideals of Islam, and used this

\footnotetext{
${ }^{70}$ See generally Kheng, Malaysia: The Making of a Nation. especially chapter 5 and 6; Virginia Matheson Hooker, "Reconfiguring Malay and Islâm in Contemporary Malaysia," in Timothy P. Barnard (ed.), Contesting Malayness: Malay Identity Across Boundaries, pp. 149-167.

${ }^{71}$ Jan Stark, "The Islamic Debate in Malaysia: The Unfinished Project," South East Asia Research 11, 1 (2003), pp. 176-7.

${ }^{72}$ Jan Stark, "Constructing an Islamic Model in Two Malaysian States: Pas Rule in Kelantan and Terengganu," Sojourn 19, no. 1 (2004), p. 52.

${ }^{73}$ Liow, “Deconstructing Political Islam in Malaysia: Umno's Response to Pas' ReligioPolitical Dialectic," p. 2.
} 
philosophy to organize students behind him in a campaign against proWestern leaders.

The step of bringing Anwar into UMNO has been interpreted as an attempt by former Prime Minister Mahathir Mohammad to weaken the Islamic opposition while at the same time strengthening the government's Islamic credentials. ${ }^{74}$ This situation has had serious implications for UMNO in their election strategy because virtually all Malays are Muslim and most Muslims in Malaysia are Malay. The problem of identity has become a source of debate within UMNO itself. Under Mahathir Islam was brought to the forefront of UMNO and Malaysian politics, and many of Mahathir's ideas were adopted by UMNO and the government. He used Islam as a wedge to attack the opposition party PAS, accusing them of not being interested in Malaysia's development. UMNO resorted to controlling the mainstream media to generate public apprehension regarding the Islamic opposition. In an attempt to define the boundaries of Islamic politics in Malaysia the UMNO-led government regularly portrays PAS members as "fanatics" and "radicals" while portraying itself as the representative of "modern" and "progressive" Islam. Provocative remarks purportedly made by PAS leaders over the years and amplified by the government-controlled media have been used to promoted negative perceptions of PAS as "fundamentalists". ${ }^{75}$

Mahathir's vision of Islam as a force for modernization and industrialization won acceptance from most non-Muslim Malaysians. Muslim Malaysians, however, tended to be uncomfortable with such ideas $^{76}$ since they seemed to imply giving special rights to "nonMalays', especially in the economy. Malays increasingly pressured the government to confer special rights on Muslims in the form of bringing back Malay culture with an Islamic coloring. ${ }^{77}$

Following the general election in 1999 the tensions increased when PAS extended its political control beyond the northeastern state of

\footnotetext{
${ }^{74}$ Jan Stark, “The Islamic Debate in Malaysia,” p. 179.

${ }^{75}$ Liow, "Deconstructing Political Islam in Malaysia: Umno's Response to Pas' ReligioPolitical Dialectic," p. 8.

${ }^{76}$ Interview with Datuk Wan Wahid, a government official in Pahang, Kuantan, July 2004.

77 This idea was discussed at a Malay Conference at Putri Pan Pacific Hotel, Johor, October 11-12 2004.
} 
Kelantan to Trengganu and become the main voice of the opposition. ${ }^{78}$ The issues of Islamic statehood, the implementation of shari'ah, and the role of women were the subject of acrimonious debate between the two parties. In early July 2001 in his address to the Convention of the Barisan Nasional coalition in Kuala Lumpur Mahathir controversially declared Malaysia to be an "Islamic State". He made a similar statement in his address at the Gerakan party Annual Delegates Conference in Kuala Lumpur on 29 September 2001.79 The following year he went even further by claiming that Malaysia was an "Islamic fundamentalist state" and could be proud of the fact. The Malaysian government's policies, he said, were consistent with the fundamental teachings of Islam. ${ }^{80} \mathrm{He}$ acknowledged that his views would shock many in the West "because they consider a fundamentalist to be someone who is violent and did all kinds of bad things". He said this perception was wrong and that it was not necessarily a bad thing to be a fundamentalist.

It was in the final years of Mahathir's prime ministership that the concept of Islam Hadhari began to be discussed in Malaysian government circles in the search for an electorally appealing concept of Islam that was distinct from PAS's demands. In 2002 a committee of 'ulama' and intellectuals held a discussion of the concept Islam Hadhari with the objective of finding a way to implement an "Islamic state" that was in line with "Malaysian civilization". JAKIM (the Department of Islamic Development of Malaysia) also started to explore the direction of Islam Hadhari. At that time JAKIM was only concerned with the aspirations of Muslim civil servants in Malaysia. ${ }^{81}$ In 2004 new Prime Minister Abdullah Ahmad Badawi announced the concept of Islam Hadhari in his speech at the $55^{\text {th }} \mathrm{UMNO}$ general assembly. ${ }^{82} \mathrm{He}$

\footnotetext{
78 See also William Case, Politics in Southeast Asia: Democracy or Less (Richmond: Curzon Press, 2003), pp. 137-43.

79 According to Zainah Anwar, this statement was unconstitutional because it was not declared formally as a new law; interview with Zainah Anwar, June 2004.

80 "Mahathir: Malaysia is "fundamentalist state" http://archives.cnn.com/2002/WORLD/asiapcf/southeast/06/18/malaysia.mahathir, accessed 15 October 2004.

81 Muhammad Syukri Salleh, "Islam Hadhari Dari Perspektif Pembangunan Berteraskan Islam,” Pemikir 39 \& 40 (2005), p. 55.

82 Abdullah Ahmad Badawi, "Moving Forward Toward Excellence," English version of address to the 55th UMNO General Assembly (2004) Kuala Lumpur, pp. 1-26;
} 
spoke about Islam Hadhari and the need for a globally competitive Malay community. He stated that "Islam Hadhari was a complete and comprehensive philosophy, with an emphasis on the development of the economy and civilization, and the building of Malay competitiveness". He also argued that Islam Hadhari was an approach that emphasized development that was consistent with the tenets of Islam and was focused on enhancing the quality of life.

Islam Hadhari was an effort to bring the ummah back to basics, to return to the fundamentals of Islamic civilization as prescribed in the Qur'an and the Hadith. In fact, this interpretation of Islam was similar to the neo-modernism promoted by Fazlur Rahman, a leading Islamic scholar from Chicago University, who has had considerable impact in Southeast Asia since the 1980s through his works and his students. ${ }^{83}$ Islam Hadhari can therefore be seen as a new name for neo-modernism in Islamic thought. This interpretation tries to open the gate of jitihäd for Muslims in the contemporary era by combining classical Islamic scholarships and Islamic civilization with modern or Western ideas and analytical methods. ${ }^{84}$

Badawi's formulation of Islam Hadhari posited ten fundamental principles which Muslim countries were obliged to accept and follow: First, faith and piety in Allah; second, a just and trustworthy government; third, a free and independent people; fourth, vigorous pursuit and mastery of knowledge; fifth, balanced and comprehensive economic development; sixth, a good quality of life for the people; seventh, protection of the rights of minority groups and women; eighth, cultural and moral integrity; ninth, safeguarding natural resources and the environment; tenth, strong defense capabilities. ${ }^{85}$

Abdullah Ahmad Badawi, "Lonjakan Perkasa Bangsa," Address to the 56th UMNO General Assembly, Kuala Lumpur 21 July 2005, pp. 1-20. See also Abdullah Ahmad Badawi, "Islam Hadhari Akan Bangkit," Pemikir 39-40 (2005), pp. 1-20; Abdullah Ahmad Badawi, Islam Hadhari: A Model Approach for Development and Progress (Selangor: MPH, 2006).

83 See generally Cone, "Neo-Modern Islam in Suharto's Indonesia," pp. 52-67; and Barton, "Neo-Modernisme: A Vital Synthesis of Traditionalist and Modernist Islamic Thought in Indonesia," pp. 1-75.

84 Barton, "Neo-Modernisme: A Vital Synthesis of Traditionalist and Modernist Islamic Thought in Indonesia," p. 7.

85 Abdullah Ahmad Badawi, "Islam Hadhari," Keynote Address at Jamia Millia Islamia, Delhi, India, 21 December 2004, available at Official Website of the Prime Minister's Office of Malaysia, www.pmo.gov.my; Abdullah Ahmad Badawi, "The Oxford Centre 
Badawi argued that the gates of $\ddot{j}$ tihäd must remain open so that interpretations are suited to the prevailing needs and conditions of the times. ${ }^{86}$ In his 2004 speech at the Jami Millia Islamia forum, Badawi suggested that the problems confronting contemporary Muslim societies today were not the problems of the sixteenth century and the solutions they need today did not lie with the notion of a shari'ah purportedly final and complete fourteen hundred years ago. ${ }^{87}$ Badawi thus demonstrated his support for the position of jitihäd in his status as prime minister, as head of the $\mathrm{BN}$, and as chairperson of the Organization of Islamic Conference. Islamic modernism and Islamic neo-modernism thus became a political agenda in Malaysia under a different name. Yet, it is clear that Badawi advanced such ideas in order to counter PAS's political activities in Malaysia, especially regarding Islamic interpretation in the political arena. In his address to the Jami Millia Islamia Badawi claimed that the opposition Pan-Malaysia Islamic Party had politicized religion to the extent that it had claimed a virtual monopoly on Islam. Badawi even accused them of canvassing for votes by telling villagers that they would be assured of heaven if they vote for PAS. 88

Badawi's strategy of Islam Hadhari was divided into stages. First, he asked the people to acknowledge that PAS's interpretation to Islam was misleading and attempted to promote and propagate Islam Hadhari to counter PAS's agenda. A special project called the Islam Hadhari Foundation was charged with disseminating the concept of Islam Hadhari to the Malaysian people through seminars and other activities. ${ }^{89}$

Numerous other departments support the Islam Hadhari campaign. One of the most prominent representative of Islamic voices in Malaysia is JAKIM, the Department of Islamic Development of

for Islamic Studies," Magdalen College, University of Oxford, 1 October 2004, available at Official Website of the Prime Minister's Office of Malaysia, www.pmo.gov.my

${ }^{86}$ Abdullah Ahmad Badawi, "Moving Forward Toward Excellence," p. 5.

87 Abdullah Ahmad Badawi, "Islam Hadhari," in Keynote Address at Jamia Millia Islamia (Delhi: 2004).

88 Abdullah Ahmad Badawi, "The Oxford Centre for Islamic Studies," (Magdalen College: University of Oxford, 2004).

${ }^{89}$ Refer to http://www.islamhadhari.org. 
Malaysia. JAKIM proposes that Islam Hadhari is Malaysia's way to implement an Islamic State. ${ }^{90}$ The official dakwah organization of Malaysia, YADIM, also supports Islam Hadhari. ${ }^{91}$ For the academic community there is the Institute of Islamic Understanding Malaysia (IKIM) which holds frequent seminars to promote Islam Hadhari among scholars in Malaysia. ${ }^{22}$ Badawi is thus able to exercise his power and authority through many channels. Islam Hadhari is therefore clearly an UMNO political agenda, but it is also colored by authority, missionary fervor, politics, as well as an academic panorama and aroma.

Badawi argued that it was PAS that politicized Islam, not UMNO. He claimed that it was not in UMNO's nature to trivialize religion. UMNO has never allowed religion to be used as a political tool, it staunchly opposes the use of Islam as an instrument to manipulate people's beliefs, and it has always ensured that Islam and Muslims are protected from such abuse of religion. ${ }^{93}$ Yet, it is clear that Islam has frequently been used as part of a political agenda in Malaysia during the era of Mahathir Mohammad, who took every opportunity to argue that Islam could be reconciled with modernization and economic development. ${ }^{44}$ For its part PAS began its life in 1951 by championing democracy and a post-colonial state founded on the teaching of Islam. ${ }^{95}$ Under Anwar Ibrahim, ABIM (the Malaysian Islamic Youth

\footnotetext{
90 http://www.islam.gov.my/islamhadhari/profil.html

${ }^{91}$ http://www.yadim.com.my

92 See http:/ /www.ikim.gov.my

${ }^{93}$ Badawi, "Moving Forward Toward Excellence," p. 5.

${ }_{94}$ Muhammad Syukri Salleh, "Recent Trends in Islamic Revivalism in Malaysia," Studia Islamika Vol. 6, No. 2 (1999), pp. 39-64; Mohammad Abu Bakar, "Islamic Revivalism and the Political Process in Malaysia," Asian Survey Vol. XXI, No. 1 (1981); Mohammad Abu Bakar, "External Influences of Contemporary Islamic Resurgence in Malaysia," Contemporary Southeast Asia Vol. 13, No. 1 (1991).

${ }^{95}$ For a study of PAS see Noor, Farish A., PAS post-Fadzil Noor: Future Directions and Prospects (Singapore: ISEAS, 2002); "The Localization of Islamist Discourse in the Tafsir of Tuan Guru Nik Aziz Nik Mat, Murshidul 'Am of PAS," in Malaysia Islam, Society and Politics, edited by V. H. a. N. Othman (Singapore: ISEAS, 2003), pp. 195-235; "Blood, Sweat and Jibad: The Radicalization of the Political Discourse of the PanMalaysian Islamic Party (PAS) from 1982 Onwards". Contemporary Southeast Asia Vol. 25, No. 2 (2003): pp. 200-232; Kamarulnizam Abdullah, The Politics of Islam in Contemporary Malaysia (Bangi: UKM Publisher, 2003). Liow, "Deconstructing Political Islam in Malaysia: Umno's Response to Pas' Religio-Political Dialectic," pp. 1-24.
} 
Movement), established in 1971, used Islam to articulate contemporary social issues such as poverty, uneven distribution of wealth, and government corruption.

Badawi's Islam Hadhari project turned out to be the winning ticket for UMNO in the general elections in 2004. Yang Razali Kassim argues that a significant outcome of the election that year was the reordering of the political landscape that was already affected by the growing political and social influence of Islam. ${ }^{96}$ The use of Islam Hadhari by UMNO as a political tool during the election campaign had successfully countered PAS's brand of Islam and its call for an Islamic state. In Badawi's address at the $56^{\text {th }}$ UMNO General Assembly in 2005 he declared that he would develop Islam Hadhari further for the empowerment of Muslim society in Malaysia. ${ }^{97}$

Islam Hadhari became a political formula for UMNO in the 20032004 struggle against the opposition. It was formulated for the purpose of countering the issue of the Islamic state that was promoted by the PAS. However, most of the Islamic institutions promote Islam Hadhari as a new way of interpreting Islam. It seems that Islam Hadhari has become a tool to develop Malaysia in the image of true Islam.

\section{Islam Progresif:}

\section{An Umbrella for the Islamic Reformation}

On the issue of the relation between Islam Progresif, Islam Liberal, and Islam Hadhari, two prominent Islamic scholars, Omid Safi and Farish Noor, have differing opinions. Farish Noor, a former fellow at the Centre for Modern Orient Studies, Berlin, ${ }^{98}$ argues that,

... this debate about Islam Hadari, Islam Liberal, Islam Progresif is misleading. There is only one Islam and these are merely approaches at trying to understand Islam and its goals in the context of the present. So I would see these as various attempts at trying to locate and contextualise the praxis of Islam in the realities of today. But there has to be one starting point, namely the fundamentals of Islam itself. There can be no addition or questioning of 'aqidah and

\footnotetext{
96 Yang Razali Kassim, "Enter the Badawi Era: Implications of Malaysia's General Election 2004," IDSS, no. 10 (2004), p. 1.

${ }^{97}$ Badawi, "Lonjakan Perkasa Bangsa".

${ }^{98}$ See Farish A. Noor, http://www.zmo.de/Mitarbeiter/Noor/main.htm
} 
imân. When that happens there is no progress or liberalism, only distortion and adaptation that is bid'ah.

So when I use the term 'Islam Progressive', I mean any application of Islamic norms and praxis that progresses from the fundamentals of Islam. Never any kind of Islam that goes against the tenets of imân and 'aqîdah. Eg: Islam is concerned with social justice, but how do we address the needs for social justice today? For me it means taking into account the effects of globalization, global capitalism, international finance etc. We cannot hide from these realities any more than we can hide from American cultural hegemony and military imperialism. So for me, Islam and Muslims have to confront these challenges, but from the starting point of Islamic fundamentals. ${ }^{99}$

Omid Safi, assistant professor of Islamic Studies at Colgate University in Hamilton, New York, and co-chair for the Study of Islam Section at the American Academy of Religion, ${ }^{100}$ summarized his views as follows,

I think you'll see that there is a difference between what I am talking about and what Charles Kurzman was doing, especially in the area of the critique of colonialism, as well a more critical attitude towards the excesses of modernity in areas of nationalism and environmental destruction, and shortcomings in racism, etc. ${ }^{101}$

"Progressive Islam" is concerned with contemporary challenges to Muslims based on iman and 'aqiidah. It has its origins with the conflict between Kaum Muda and Kaum Tua in Padang and also some parts of Malaya in the early nineteenth century. ${ }^{102}$ Farish Noor maintains that the roots of the progressive Islamist project are in the Malay Archipelago. It began when this generation of modernist-reformist

\footnotetext{
${ }^{99}$ Email correspondence with Farish Noor, 23 October 2005.

100 See Omid Safi, http://classes.colgate.edu/osafi/

${ }^{101}$ Email correspondence with Omid Safi, 26 October 2005.

102 Murni Djamal, "The Origin of the Islamic Reform Movement in Minangkabau: Life and Thought of Abdul Karim Amrullah," Studia Islamika 5, no. 3 (1998), pp. 1-45; Roff, The Origins of Malay Nationalism. Ahmed Ibrahim Abushouk, "Al-Manâr and the Hadhramî Elite in the Malay-Indonesia World: Challenge and Response," JSRAS 17, no. 3 (2007), pp. 301-22.
} 
thinkers, activists, and 'ulamä' in the nineteenth century ${ }^{103}$ spread the ideas of the reformists from the Middle East, influenced by tahayyul, bid'ah (heretical innovations), and khurafat, with the intention of purifying Muslim tradition practices. ${ }^{104}$ During the period of intense political, discursive and at times physical conflict between the Kaum Muda reformists and the Kaum Tua we find the terms pembaharuan (renewal), nabdah (rebirth, renaissance) and modernisme (modernity) being introduced into the discursive economy of normative Islam for the first time. ${ }^{105}$

Progressive Islam develops, Islamic reformism based on such ideas as tajdid and islăh. Tajdd is usually translated as "renewal" and islăh as "reform", while ibya' means revival. Some scholars also use the Arabic word nahdah which translates as "rising," "awakening," "revival," or "renaissance". Historically, this term began to be used from the end of World War I. According to Jacques Waardenburg, the term "reform" (islāh) has three different meanings. ${ }^{106}$ The first meaning connotes a return to the spiritual core of a religious tradition. In this context, the islă movement in Islam desired to return to the essential principles of the Qur'an as well as the early Sunnah (Prophetic traditions). The second meaning of "reform" is the adaptation of a religion to modern times and its demands which are different from those of earlier times. The third meaning of "reform" suggests the conscious introduction of self-critical reasoning in the religious domain, such as that expressed by the term "Reform Judaism".

These terms relate to the work and writings of Muhammad 'Abduh and Rashìd Rid̄ā. In Southeast Asia, their ideas were spread by Shaykh Tăhir Jalāl al-Dīn al-Azhari, a former student of Ahmad Khațib and

\footnotetext{
103 Noor, “The Challenges and Prospects for 'Progressive Islam' in Southeast Asia: Reclaiming the Faith in the Age of George Bush and Osama Ben Laden," p. 9.

${ }^{104}$ For example see Taufik Abdullah, "Adat and Islam: An Examination of Conflict in Minangkabau," Indonesia No.2 (1966), pp. 1-24; Taufik Abdullah, "Adat and Islam: An Examination of Conflict in Minangkabau," in Ibrahim (eds), Readings on Islam, pp. 94102; Firdaus Haji Abdullah, Radical Malay Politics: Its Origin and Early Development (Kuala Lumpur: Pelanduk, 1985), pp. 17-9; Abdullah, The Politics of Islam in Contemporary Malaysia, pp. 40-3.

105 Noor, "The Challenges and Prospects for 'Progressive Islam' in Southeast Asia: Reclaiming the Faith in the Age of George Bush and Osama Ben Laden," p. 9.

${ }^{106}$ Jacques Waardenburg, n.d., pp. 1-3.
} 
Syed Shaykh al-Hāì in Minangkabau. ${ }^{107}$ Farish Noor regards these figures as the founding fathers of Progressive Islam and the Islamic modernist movement Kaum Muda in Southeast Asia. ${ }^{108}$ In Indonesia these ideas were also promoted by Agus Salim through his organization Jong Islamieten Bond in 1925 and H.O.S. Tjokroaminoto through Sarekat Islam. ${ }^{109}$ Agus Salim was also a student of Shaykh Aḥmad Khațib. Riddell notes that "Haji Agus Salim, like Muhammad Țăhir bin Jalāl al-Dīn al-Azhari, was related to Ahmad Khațīb, and studied while posted to the Dutch Consulate in Jeddah during the period 1904-13". ${ }^{110}$ Shaykh Ahmad Khatịb, however, was the originator of the Islamic reform movement in the Minangkabau area, and propagated his ideas in Makkah throughout the last two decades of the nineteenth century and the early years of the present century. ${ }^{111} \mathrm{It}$ is clear, therefore, that the idea of Progressive Islam originated with Shaykh Aḥmad Khațiib and his students, Shaykh Ṭăhir bin Jalāl al-Dīin al-Azhariand Agus Salim.

Over the last decade, the concept of Progressive Islam has not been discussed in a formal way like Islam Liberal and Islam Hadhari. For Omid Safi,

The various understandings of Islam which fall under the rubric of 'progressive' are both continuations of, and radical departures from, the one-hundred-fifty-year old tradition of liberal Islam. Liberal advocates of Islam generally display an uncritical, almost devotional identification with modernity, and often (but do not always) by-pass discussions of colonialism and imperialism. Progressive advocates of Islam [...] are almost uniformly critical of colonialism, both of its nineteenth century manifestation and its current variety. Progressive Muslims

${ }^{107}$ Djamal, "The Origin of the Islamic Reform Movement in Minangkabau: Life and Thought of Abdul Karim Amrullah," p. 9; Murni Djamal, Dr. H. Abdul Karim Amrullab: Pengarubnya Dalam Gerakan Pembaharuan Islam Di Minangkabau Pada Awal Abad Ke-20 (Jakarta: INIS, 2002); Farish A. Noor, From Majapahit to Putrajaya: Searching for Another Malaysia (Kuala Lumpur: Silverfishbooks, 2005), p. 165.

108 Noor, From Majapabit to Putrajaya: Searching for Another Malaysia, p. 165.

109 Ibid., pp. 163-5.

${ }^{110}$ Riddel, Islam and the Malay-Indonesian World: Transmission and Responses, p. 214.

111 Djamal, "The Origin of the Islamic Reform Movement in Minangkabau: Life and Thought of Abdul Karim Amrullah.” 
espouse a critical and non-apologetic 'multiple critique' with respect to both Islam and modernity. They are undoubtedly postmodern in the sense of their critical approach to modernity. That double engagement with the varieties of Islam and modernity, plus an emphasis on concrete social action and transformation, is the defining characteristic of progressive Islam today. ${ }^{112}$

The concept of progressive Islam has not been formally institutionalized like Islam Hadhari and Islam Liberal. In Southeast Asia, every Islamic movement that introduces progressive ideas such as human rights, justice, gender, and equality can be regarded as "progressive". Omid Safi points to the works of Muzaffar and Farish Noor as being progressive in this sense. Muzaffar, is a leading scholar in Malaysia with his Just World Trust (JUST). ${ }^{113}$ He has been very critical of the policies of the Malaysian government, as well as of the West and also Islamic revivalist groups". ${ }^{114}$ Muzaffar has also been heavily involved in religious dialogue in Malaysia. For Muzaffar, common values among religions,

Can be divided into five categories. One, attitudes and orientations which help to make the individual a morally better person and, at the time, elevate the ethical content and quality of society. Two, attitudes and orientations which have a negative impact upon the individual and society, and therefore, contribute towards our understanding and appreciation of the positive moral

\footnotetext{
112 Safi, "What Is Progressive Islam," p. 48.

113 Chandra Muzaffar was born in 1947 in Bedong (Kedah). He is a graduate of University of Singapore where he obtained hi PhD in Social Sciences (1977). From 1970 to 1983 he was a professor at the University of Malaysia in political science. In 1985 he became a member of the executive committee of the Asian Commission on Human Rights. In October 1987 he was arrested by the Malaysian government and released without condition in December 1987. In 1988 he was nominated by "Human Rights Watch" as a monitor. In 1989 he was appointed to the National Economic Consultative Committee of UMNO. He resigned his position in 1990 to protest the policies of the committee. In 1992 he was appointed a member of the Malaysian Economic Research Institute (MERI) which he held until 1999. He was formerly Deputy President of Kealidan (National Justice Party), founded in 1998 by Wan Azizah Ismail, the wife of Anwar Ibrahim, the former Deputy Prime Minister jailed for corruption and sodomy; http://www.asian-affairs.com/biographies/muzafarcv.html, accessed 30 October 2005.
}

114 Riddell, Islam and the Malay-Indonesian World, p. 255. 
values that we must uphold. Three, values associated with institutions or the human being's larger environment which serve to enhance the moral ballast of human existence. Four, worldviews and visions associated with the meaning of life and life processes which suggest that the different religions may, in some respects share similar outlooks on what they consider important in life. Five, realities pertaining to the human being and the human condition which, on reflection, seem to suggest that there are common virtues and vices in actual human behaviour that transcend religious dichotomies. ${ }^{115}$

Muzaffar proposes that there are certain universal values brought by religion into the world. These include concepts of good and bad, right and wrong, and issues of ethics and morality. The subject of religious ethics has also been much discussed by Indonesian scholars such as Madjid, Wahid, and Abdullah. Islam Liberal activists in Indonesia have also put forward the issue of religious dialogue between Islam and other religions in Indonesia. In Malaysia, Muzaffar suggests that not enough emphasis has been given to developing shared principles and ethics in public life. ${ }^{116}$ Even though Malaysia is a multi-ethnic state, Malaysia's races live peacefully, but separately - they have separate schools, separate friends, and separate social lives. ${ }^{117}$ However according to Muzaffar, it is partly because multi-ethnic Malaysia continues to hold together that the ruling elite and the influential social stratum in general do not need to introduce a novel idea into the nation-building process - that of emphasizing common values shared by the different religious communities in the country. ${ }^{118}$ It seems that progressive Islam is similar to other streams of Islamic thought in Southeast Asia, especially the modernists and neomodernists, although it tends to be more anti-American and is opposed to American hegemony in the region.

\footnotetext{
115 Chandra Muzaffar, "Common Values of the Religions and Faiths in Malaysia," JUST: International Movement for a Just World http://www.just-international.org/article.cfm?newsid=20000243, accessed 30 October 2005.

116 Ibid.

117 M. Jegathesan, "Malaysia's races live peacefully, but separately," Bangkok Post, 29 August 2005.

118 Chandra Muzaffar, "Common Values of the Religions and Faiths in Malaysia".
} 


\section{Conclusion}

As an intellectual movement, Islam Liberal differs from Islam Hadhari in that it does not originate from government sources. Islam Progresif, on the other hand, is more of an umbrella term referring to various strands of thought developed by Muslims opposed to the status quo. Although Islam Hadhari is a newly-coined term, it in fact contains many elements in common with other schools of Islamic thought including Islam Liberal and neo-modernist Islam. The rise of Islam Liberal is a response to the increased prominence of hard-line Islamic movements in Indonesia. It is more of a "bottom up" movement supported by many intellectuals, not only in Indonesia but also in America and the Middle East. In this context, Islam Progresif can be seen as the inheritor of the historical tradition of Islamic reformism in Southeast Asia. In recent years, however, Islam Progresif has tended to be used by some scholars to criticize both Southeast Asian governments and the West, especially America.

In fact, the labeling of Islamic thought is quite confusing for many Southeast Asian Muslims. In Malaysia, many Malays still reject the concept of Islam Hadhari because of its name, while in Indonesia many see the Liberal Islam Network as an orientalist organization which promotes the thinking of infidels. In comparing the different schools of thought and the periods in which they have been developed, perhaps Khaled Abou El-Fadl makes the most apt observation: "All Islamic groups and organization claim to adhere to the fundamentals of Islam; Even the most liberal movement will insist that its ideas and convictions better represent the fundamentals of the faith." ${ }^{119}$ []

\section{Bibliography}

\section{Books and Articles}

Abdullah, Firdaus Haji. Radical Malay Politics: Its Origin and Early Development. Kuala Lumpur: Pelanduk, 1985.

Abdullah, Kamarulnizam. The Politics of Islam in Contemporary Malaysia. Bangi: UKM Publisher, 2003.

Abdullah, M. Amin. "Al-Ta'wîl Al-'Ilmî: Ke Arah Perubahan Paradigma Penafsiran Kitab Suci." Al-Jâmi'ab: Journal of Islamic Studies 39, 2 (2001): 359-91.

${ }^{119} \mathrm{Fadl}$, The Great Theft: Wrestling Islam from the Extremists, p. 18. 
Dinamika Islam Kultural: Pemetaan Atas Wacana Keislaman Kontemporer. Edited by M. Muchlas Rowi, Hilman Latief and Asep P.B. Bandung: Mizan, 2000.

. Falsafah Kalam Di Era Postmodernisme. Edited by Muh. Sungaidi Ardani. Yogyakarta: Pustaka Pelajar, 1995.

"Kajian Ilmu Kalam Di Iain Menyongsong Perguliran Paradigma Keilmuan Keislaman Pada Era Milenium Ketiga." Al-Jâmi'ab: Journal of Islamic Studies 65, 6 (2000): 78-101.

-. "New Horizons of Islamic Studies through Socio-Cultural Hermeneutics." Al-Jâmi'ah: Journal of Islamic Studies 41,1 (2003): $1-24$.

-. "Preliminary Remarks on the Philosophy of Islamic Religious Science." Al-Jâmi'ah: Journal of Islamic Studies 61 (1998): 1-26.

- Studi Agama: Normativitas Atau Historisitas? Edited by Muh. Sungaidi Ardani. Yogyakarta: Pustaka Pelajar, 1996.

"Telaah Hermenetis Terhadap Masyarakat Muslim Indonesia." In Kontektualisasi Ajaran Islam: 70 Tabun Prof. Dr. H. Munawir Sjadzali, Ma, edited by Muhammad Wahyuni Nafis, Budhy Munawar Rachman, Elza Peldi Taher and Agus Wahid, 537-54. Jakarta: Paramadina, 1995.

Abdullah, Taufik. "Adat and Islam: An Examination of Conflict in Minangkabau." Indonesia No.2 (1966): 1-24.

"Adat and Islam: An Examination of Conflict in Minangkabau." In Readings on Islam in Southeast Asia edited by Ahmad Ibrahim, Sharon Siddique and Yasmin Hussain, 94-102. Singapore: ISEAS, 1985.

Abu Bakar, Mohammad. "External Influences of Contemporary Islamic Resurgence in Malaysia." Contemporary Southeast Asia Vol.13, No.1 (1991): 220-28.

-------. "Islamic Revivalism and the Political Process in Malaysia." Asian Survey Vol.XXI, No.1 (1981): 1040-59.

Abushouk, Ahmed Ibrahim. "Al-Manâr and the Hadhramî Elite in the Malay-Indonesia World: Challenge and Response." JSRAS 17, no. 3 (2007): 301-22. 
Anderson, Benedict O'Gorman. "Perspective and Method in American Research on Indonesia." In Interpreting Indonesian Politics: Thirteen Contribution to the Debate edited by Benedict Anderson and Audrey Kahin. New York: Cornell University, 1982.

Arkoun, Mohammed. "The Concept of Authority in Islamic Thought: La Hukma Illa Lillâh." In The Islamic World: From Classical to Modern Times, edited by C.E. Boswirth, Charles Issawi, Roger Savory and A.L. Udovitch, 31-54. Darwin: The Darwin Press, 1989.

Azra, Azyumardi. Islam Reformis Dinamika Intelektual Dan Gerakan. Jakarta: RajaGrafindo Persada, 1999.

-. The Origins of Islamic Reformism: Networks of Malay-Indonesian and Middle Eastern 'Ulama in the 17th and 18th Centuries. Hawaii: University of Hawaii Press, 2004.

---------. "The Transmission of Islamic Reformism to Indonesia: Networks of Middle Eastern and Malay-Indonesian 'Ulama' in the Sevententh and Eighteenth Centuries." Ph.D. Diss., Columbia University, 1992.

Badawi, Abdullah Ahmad. "Islam Hadhari." In Keynote Address at Jamia Millia Islamia. Delhi, 2004.

---------. "Islam Hadhari Akan Bangkit." Pemikir 39-40 (2005): 1-20.

--------. Islam Hadhari: A Model Approach for Development and Progress. Selangor: MPH, 2006.

--------. "The Oxford Centre for Islamic Studies." Magdalen College: University of Oxford, 2004.

Barnard, Timothy P., ed. Contesting Malayness: Malay Identity across Boundaries. Singapore: Singapore University Press, 2006.

Barton, Greg. Gagasan Islam Liberal Di Indonesia: Pemikiran NeoModernisme Nurcholish Madjid, Djohan Effendi, Ahmad Wabib, Dan Abdurrabman Wabid. Jakarta: Paramadina, 1999. -. "Indonesia's Nurcholish Madjid and Abdurrahman Wahid as Intellectual Ulama: The Meeting of Islamic Traditionalism and Modernist in Neo-Modernist Thought." Islam and ChristianMuslim 8,3 (1997): 337-42. 
-. "Neo-Modernisme: A Vital Synthesis of Traditionalist and Modernist Islamic Thought in Indonesia." Studia Islamika 2,3 (1995): 1-75.

Benda, Harry J. "Christian Snouck Hurgronje and the Foundations of Dutch Islamic Policy in Indonesia." The Journal of Modern History 30,4 (1958): 338-47.

Budiwanti, Erni. "The Impact of Islam on the Religion of the Sasak in Bayan, West Lombok." Kultur 2, no. 2 (2001): 29-40.

Burhanuddin, Jajat. "The Fragmentation of Religious Authority: Islamic Print Media in Early 20th Century Indonesia." Studia Islamika 11, no. 1 (2004): 25-62.

Bustamam-Ahmad, Kamaruzzaman. "Islam Hadhari and Islam Liberal in Southeast Asia." In Congress of Democrats from the Islamic World "Beyond Elections: Islam and Political Parties in Southeast Asia" Jakarta: National Democratic Institute, 2005.

--------. Islam Historis: Dinamika Studi Islam Di Indonesia. Yogyakarta: Galang Press, 2002.

-. "Kontribusi Azyumardi Azra Dalam Studi Sejarah Sosial Islam Di Asia Tenggara." Profetika: Jurnal Studi Islam 5,2 (2003): 180-204.

-------. "Metamorfosis Pemikiran Intelektual Muda Nu: Suatu Pandangan Dari Outsider Nu." Millah 4,1 (2004): 111-26.

-. "Studi Sejarah Sosial Islam Di Asia Tenggara: Kontribusi Azyumardi Azra." Mimbar Agama \& Budaya XX,3 (2003): 24970 .

Wajah Baru Islam Di Indonesia. Yogyakarta: UII Press, 2004.

Case, William. Politics in Southeast Asia: Democracy or Less Richmond: Curzon Press, 2003.

Cone, Malcom. "Neo-Modern Islam in Suharto's Indonesia." New Zealand Journal of Asian Studies 4, no. 2 (2002): 52-67.

Daly, HP. Hukum Perkawinan Islam: Suatu Studi Perbandingan Dalam Kalangan Ablul-Sunnah Dan Negara-Negara Islam. Jakarta: Bulan Bintang, 1989.

Daudy, Ahmad. Syeikh Nuruddin Ar-Raniry (Sejarah, Karya Dan Sanggahan Terbadap Wujudiyyah Di Aceh). Jakarta: Bulan Bintang, 1978. 
Djamal, Murni. Dr. H. Abdul Karim Amrullab: Pengarubnya Dalam Gerakan Pembaharuan Islam Di Minangkabau Pada Awal Abad Ke20. Jakarta: INIS, 2002.

--------. "The Origin of the Islamic Reform Movement in Minangkabau: Life and Thought of Abdul Karim Amrullah." Studia Islamika 5, no. 3 (1998): 1-45.

Effendy, Bahtiar. "What Is Political Islam? An Examination of Its Theoretical Mapping in Modern Indonesia." In A Portrait of Contemporary Indonesian Islam edited by Chaider S. Bamualim, 915. Jakarta: CLS and KAS, 2005.

Esposito, John L., and John O. Voll. Makers of Contemporary Islam. Oxford: Oxford University Press, 2001.

Fadl, Khaled Aboue El. The Great Theft: Wrestling Islam from the Extremists. San Fransisco: Harper San Fransico, 2005.

Fathurahman, Oman. Tanbîh Al-Mâsŷ̂̀ Menyoal Wahdatul Wujud: Kasus Abdurrauf Singkel Di Aceh Abad 17. Bandung: Mizan, 1999.

Federspiel, Howard M. "Muslim Intellectual in Southeast Asia." Studia Islamika 6,1 (1999): 41-76.

Geertz, Clifford. The Religion of Java. Chicago and London: The University of Chicago Press, 1960.

-. "The Religion of Java." In Readings on Islam in Southeast Asia, edited by Ahmad Ibrahim, Sharon Siddique and Yasmin Hussain, 271-77. Singapore: ISEAS, 1985.

Hidayat, Komaruddin. "Contemporary Liberal Islam in Indonesia, Pluralism, and the Secular State." In A Portrait of Contemporary Indonesian Islam, edited by Chaider S. Bamualim, 53-66. Jakarta: Center for Languages and Cultures and Konrad Adenauer Stiftung, 2005.

Inglis, Fred. Clifford Geertz: Culture, Customs and Ethics. Cambridge: Polity Press, 2000.

Jaiz, Hartono Ahmad. Ada Pemurtadan Di Iain Jakarta: Al-Kautsar, 2005.

Kahn, Joel S. Other Malays: Nationalism and Cosmopolitanism in the Modern Malay World. Singapore: Singapore University Press, 2006. 
Kassim, Yang Razali. "Enter the Badawi Era: Implications of Malaysia's General Election 2004." IDSS, no. 10 (2004).

Kheng, Cheah Boon. Malaysia: The Making of a Nation. Singapore: ISEAS, 2002.

Kim, Khoo Kay. Malay Society Transformation \& Democratisation: A Stimulating and Discerning Study of the Evolution of Malay Society. 3 ed. Selangor: Pelanduk, 2001.

Kuntowijoyo. Muslim Tanpa Masjid: Esai-Esai Agama, Budaya, Dan Politik Dalam Bingkai Strukturalisme Transendental. Bandung: Mizan, 2001.

Kurzman, Charles. "Introduction: Liberal Islam and Its Islamic Context." In Liberal Islam: A Source Book, edited by Charles Kurzman, 3-26. New York and Oxford: Oxford University, 1998.

-. "Introduction: The Modernist Islamic Movement." In Modernist Islam, 1840-1940: A Sourcebook, edited by Charles Kurzman. Oxford: Oxford University Press, 2002. -. "Liberal Islam: Prospects and Challenges." Middle East Review of International Affairs 2, no. 2 (1999): 11-9.

Liow, Joseph. "Deconstructing Political Islam in Malaysia: Umno's Response to Pas' Religio-Political Dialectic." In Working Paper, 1-24. Singapore: Institute of Defence and Strategis Studies, 2003.

Lubis, Nina Herlina. "Religious Thoughts and Practices of the Kaum Menak: Strengthening Traditional Power." Studia Islamika 10, no. 2 (2003): 1-31.

Lukito, Ratno. Islamic Law and Adat Encounter: The Experience of Indonesia. Jakarta: Logos, 2001.

--. "Islamic Law and the Colonial Encounters: The Experience of India and Indonesia." In The Dynamics of Islamic Civilization, edited by Yudian Wahyudi, Akh. Minhaji and Amirul Hadi, 20930. Yogyakarta Titian Ilahi Press, 1998.

Pergumulan Antara Hukum Islam Dan Adat Di Indonesia. Jakarta: INIS, 1998. 
-. "The Role of Custom in the Formation of Islamic Law." Mc Gill Journal of Middle East Studies 5 (1997): 5-31.

Madjid, Nurcholish. "Islamic Roots of Modern Pluralism: Indonesian Experiences." Studia Islamika 1, no. 1 (1994): 55-77.

Martin, Richard C. Islamic Studies: A History of Religious Approach New Jersey: Prentice Hall: Prentice Hall, 1996.

Milner, Anthony. The Invention of Politics in Colonial Malaya: Contesting Nationalism and the Expansion of the Public Sphere. Cambridge: Cambridge University Press, 1995.

Muzani, Saiful. "Mu'tazilah Theology and the Modernization of the Indonesian Muslim Community: Intellectual Portrait of Harun Nasution." Studia Islamika 1,1 (1994): 91-132.

Noor, Farish A. "The Challenges and Prospects for 'Progressive Islam' in Southeast Asia: Reclaiming the Faith in the Age of George Bush and Osama Ben Laden." ICIP JOURNAL 1, no. 1 (2004).

---------. From Majapabit to Putrajaya: Searching for Another Malaysia Kuala Lumpur: Silverfishbooks, 2005.

Othman, Mohammad Redzuan. "In Search of and Islamic Leader: Malay Perceptions of Ibn Sa'ûd and the Domination of the Wahhabîs Saudi Arabia." Studia Islamika 11,2 (2004): 257-74.

-------. Islam Dan Masyarakat Melayu: Peranan Timur Tengah. Kuala Lumpur: UM Press, 2005.

Pranowo, M. Bambang. "From Aliran to Liberal Islam: Remapping Indonesian Islam." In A Portrait of Contemporary Indonesian Islam edited by Chaider S. Bamualim, 27-34. Jakarta: CLC and KAS, 2005.

Reid, Anthony. "Completing the Circle: Southeast Asian Studies in Southeast Asia." In ARI Working Paper, 1-9. Singapore: ARI, 2003.

Riddel, Peter G. Islam and the Malay-Indonesian World: Transmission and Responses. Singapore: Horizon Books, 2003.

-. "Schools of Islamic Thought in Southeast Asia." In Islam in Southeast Asia and China: Regional Faithlines and Faultines on the Global Ummah. Hong Kong, 2002. 
Roff, William. "Indonesian and Malay Students in Cairo in the 1920's." Indonesia 9 (1970): 73-87.

--------. "Kaum Muda-Kaum Tua: Innovation and Reaction Amongst the Malays, 1900-41." In Readings on Islam in Southeast Asia edited by Ahmad Ibrahim, Sharon Siddique and Yasmin Hussain, 12329. Singapore: ISEAS, 1986.

-. The Origins of Malay Nationalism. New Have: Yale University Press., 1967.

Safi, Omid. "What Is Progressive Islam." ISIM Newsletter, no. 13 (2003): 48.

Saleh, Fauzan. Modern Trends in Islamic Theological in Twentiethcentruy Indonesia: A Critical Survey. Leiden: Brill, 2001.

Salleh, Muhammad Syukri. "Islam Hadhari Dari Perspektif Pembangunan Berteraskan Islam." Pemikir 39 \& 40 (2005): 5388.

---------. "Recent Trends in Islamic Revivalism in Malaysia." Studia Islamika Vol.6, No.2 (1999): 39-64.

Santoso, M.A. Fattah. "Fenomena Jaringan Islam Liberal (Jil) Sebuah Studi Pendahuluan." Profetika: Jurnal Studi Islam 5, no. 2 (2003): 155-79.

Stark, Jan. "Constructing an Islamic Model in Two Malaysian States: Pas Rule in Kelantan and Terengganu." Sojourn 19, no. 1 (2004).

-------. "The Islamic Debate in Malaysia: The Unfinished Project." South East Asia Research 11,1 (2003).

Wahid, Abdurrahman. Prisma Pemikiran Gus Dur. Yogyakarta: LKiS, 1999.

Wolf-Gazo, Ernest. "Contextualizing Averroes within the German Hermeneutic Tradition." Alif: Journal of Comparative Poetics 16 (1996): 133-63. 